\title{
SELF AND OTHER IN CRITICAL INTERNATIONAL THEORY: ASSIMILATION, INCOMMENSURABILITY AND THE PARADOX OF CRITIQUE*
}

\author{
Vassilios Paipais
}

\author{
Paper accepted for publication in the \\ REVIEW OF INTERNATIONAL STUDIES
}

\begin{abstract}
:
This paper is principally concerned with the way some sophisticated critical approaches in International Relations (IR) tend to compromise their critical edge in their engagement with the self/other problematic. Critical approaches that understand critique as total non-violence towards, or unreflective affirmation of, alterity risk falling back into precritical paths, i.e. either a particularistic, assimilative universalism with pretensions of true universality or radical incommensurability and the impossibility of communication with the other. This is what this paper understands as the paradox of the politics of critique. Instead, what is more important than seeking a final overcoming or dismissal of the self/other opposition is to gain the insight that it is the perpetual striving to preserve the tension and ambivalence between self and other that rescues both critique's authority and function.
\end{abstract}

Vassilios Paipais is a research student at the International Relations Department of the London School of Economics and Political Science and an LSE100 Tutorial Fellow. He is currently co-Convenor of CRIPT, a BISA working group, and his interests include International Relations theory, political theory, international political theory, international ethics, strategic studies and military history.

*I would like to thank George Papanicolaou, Felix Berenskoetter and two anonymous referees of this journal for their helpful and constructive criticism. Above all, I am indebted to professor Kimberly Hutchings for being a constant source of intellectual stimulation and encouragement throughout the process of writing this essay. The remaining mistakes are of course all mine. 


\section{Introduction}

Since the time of the pre-Socratic philosophers, one of the most persistent and pervading questions in Western philosophy has been the 'problem' of the one and the many and/or identity and difference. As Richard Bernstein notes, "Western philosophy began with this 'problem': philosophers have always been concerned with understanding what underlies and pervades the multiplicity, diversity, and sheer contingency that we encounter in our everyday lives". ${ }^{1}$ It is, then, by no means a coincidence that the main dissatisfactions with the project of European modernity, at least since Nietzsche, converged around the criticism that the dominant tendency in Western philosophy and metaphysics has been to privilege and valorise unity, harmony, totality and, thereby, to denigrate, suppress, or marginalise multiplicity, contingency, particularity, singularity. Similarly, until the advent of Critical Theory and post-structuralist approaches in International Relations (IR $)^{2}$, the prioritisation of sameness over difference had been scarcely recognised as such by the debates in the field, even though it implicitly permeated the underlying epistemological and ontological assumptions of the various mainstream theories that competed for exegetic primacy in the discipline. Nonetheless, although the issue of exposing the practices of exclusion and eradication of difference, against what was seen as the naturalisation of historically contingent power structures, was gradually recognised as

\footnotetext{
${ }^{1}$ Richard J. Bernstein, The New Constellation (Cambridge: Polity Press, 1991), p. 58.

${ }^{2}$ In the context of International Relations, the terms 'Critical Theory' and 'post-structuralism' are used to refer to theorists relating their work to the Frankfurt School (particularly Habermas), on the one hand, and to primarily French post-structuralist theorists (Derrida, Foucault, Lyotard and Levinas), on the other. Within this essay the work of Linklater, who mainly relies on Habermas, and Shapcott, who relies on Habermas and Gadamer, is used to exemplify 'Critical Theory' and, in particular, their own critical version of dialogic cosmopolitanism; the work of Ashley and Walker, and Campbell is used to exemplify 'post-structuralism'. The term 'critical approaches' is alluding to both types of critical theorising in IR.
} 
a legitimate and long-missing critique in the field of $\mathrm{IR},{ }^{3}$ it is not yet clear what this recognition entails in terms of the possibility of transcending the division between identity and difference. In other words, do critical approaches in IR succeed in articulating a true reconciliation between self and other without objectifying the other's alterity? Or does any effort to avoid committing injustice to difference inescapably foreclose any possibility of communication between self and other?

To begin with, the analysis will build on the distinction between the relative and the absolute interpretation of otherness most prominently found in the work of two philosophers both belonging to the phenomenology tradition, Georg Hegel and Emmanuel Levinas. The main argument this paper will be putting forward is that, in responding to the 'enigma' of otherness through either a relative or an absolute understanding of alterity, the most promising critical approaches in IR theory tend to oscillate between two equally uncritical options: they either compromise the other's true alterity so she or he becomes a mirror image of the self or, in fear of some totalising reduction bordering on violence, make the difference between sameness and strangeness so inaccessible that communication becomes impossible. Put differently, the argument is that albeit driven by different aspirations - namely either to bridge the gap between identity and difference or to question the prioritisation of identity by calling for a strategic preoccupation with alterity - critical theorising in IR appears to compromise its critical edge through relapsing into either assimilationism or radical incommensurability. Yet, it should be noted that drawing any authoritative generalisations over the capacity of critical IR theory in toto to articulate otherness persuasively is beyond the scope of this paper. Rather, by presenting the limitations and contradictions of some nuanced critical approaches in IR theory in their treatment

\footnotetext{
${ }^{3}$ See, for instance, Yosef Lapid, 'The Third Debate: On the Prospects of International Theory in a Post-Positive Era', International Studies Quarterly 33 (1989), pp. 235-54.
} 
of alterity, this paper offers not an exhaustive account but a suggestive indication of the paradoxes involved in the politics of critique when applied on the self/other problematique.

\section{Hegel and relative otherness}

In his Justice, Community and Dialogue in International Relations, Richard Shapcott engages with the work of Tzvetan Todorov in an effort to unpack the patterns of interaction that emerge when the self encounters the other for the first time. ${ }^{4}$ In Todorov's study, the two sides of the Indians and the Spanish, after the shock of the first encounter, engage in a series of different types of relationships that range from aggressive forms of interaction like enslavement, colonialism and conquest to milder ones but still within the horizon of European self-understanding like communication, love and knowledge. According to Shapcott, these terms attempt to reveal and explain what sorts of moral action are generated by the knowledge (or ignorance) of the other's alterity. Unlike Wendt ${ }^{5}$, who stresses the importance of the first gestures that signal the quality of the contact between Ego and Alter, Todorov points to deeply entrenched worldviews that predetermine both the gestures and the contact. This is more than obvious in Columbus' egocentric confrontation with the other. Columbus discovers the Indians, but not their alterity, since it seems that even before the initial contact he relies on a set of conceptual preconditions and practices which are a result of his previous acculturation in a late medieval Christian

\footnotetext{
${ }^{4}$ See Richard Shapcott, Justice, Community and Dialogue in International Relations (Cambridge: Cambridge University Press, 2001), pp. 14-29 and Tzvetan Todorov, The Conquest of America: The Question of the Other (New York: Harper \& Row, 1984).

${ }^{5}$ See Alexander E. Wendt, 'Anarchy is What States Make of It: The Social Construction of Power Politics', International Organization 46 (1992), pp. 391-425.
} 
environment. Todorov labels the behaviour that derives from this pattern of preconceptions a 'double movement':

Either he conceives the Indians (though without using these words) as human beings altogether, having the same rights as himself; but then he sees them not only as equals but also as identical, and this behavior leads to assimilationism, the projection of his own values on the others. Or else he starts from the difference, but the latter is immediately translated into terms of superiority and inferiority (in his case, obviously, it is the Indians who are inferior) ... These two elementary figures of the experience of alterity are both grounded in egocentrism, in the identification of our own values with values in general, of our I with the universe - in the conviction that the world is one. ${ }^{6}$

Shapcott is effectively employing Todorov's study to highlight that the most likely outcome of trying to make sense of difference in our own terms before the actual engagement with alterity would be the inability to establish genuine communication with the other. Our discovery of difference is haunted by our efforts to engage with alterity in a meaningful (to us) way. In a similar vein, Inayatullah and Blaney argue that what is truly other in alterity remains beyond immediate recognition:

[t]he initial revelation of difference by the self is 'translated' as the 'inferiority' of the other. Further contact may lead to the discovery or construction of commonality. However, this commonality (and purported equality) is established at the price of the disregard of difference, leading to a projection of values on the other, a demand for assimilation. $^{7}$

\footnotetext{
${ }^{6}$ Todorov, The Conquest of America, pp. 42-43.

${ }^{7}$ Naeem Inayatullah and David L. Blaney, 'Knowing Encounters: Beyond Parochialism in International Relations Theory', in The Return of Culture and Identity in IR Theory, ed. Yosef Lapid and Friedrich Kratochwil (Boulder London: Lynne Rienner, 1996), p. 75. For a more comprehensive treatment of the
} 
Equally, Connolly argues that conquest and conversion function together as premises and signs of superiority: "each supports the other in the effort to erase the threat that difference presents to the surety of self-identity". ${ }^{8}$ What both Todorov and Connolly describe here is a pre-Hegelian state of affairs: in the process of realising its project of identification, the individual constructs its identity in relation to a series of differences which are recognised by a knowing subject as objects of knowledge and are, subsequently, converted into otherness in order to secure its own self-certainty.

However, as Hegel explains time and again in the Phenomenology of Spirit ${ }^{9}$ through the enumeration of the repeated failures of the subject's endeavours - he calls them 'shapes of consciousness' - to impose his vision on the social universe, the 'big Other' of the social substance always returns to upset the self's teleological project. ${ }^{10}$ Hegel is never tired of reminding us that the very fact of identity's constitution through differentiation contributes to its inherent instability. In fact, Hegel's renowned sections on the master-slave dialectic can actually be construed as one of the most trenchant theoretical accounts of the subject's failed process of identification. In the paragraphs which preface the Lordship and Bondage section (paras 166-177) Hegel tells us that "self consciousness is desire" and as such is "certain of itself only by superseding the other", "certain of the nothingness of this other" and that self-consciousness achieves only an imperfect realisation of this desire

problem see Naeem Inayatullah and David L. Blaney, International Relations and the Problem of Difference (New York and London: Routledge, 2004).

${ }^{8}$ William E. Connolly, Identity/Difference: Democratic Negotiations of Political Paradox (Ithaca, NY: Cornell University Press, 1991), p. 43. Connolly's book here, as previously Todorov's and Inayatullah \& Blaney's, are used to set up the contours of a pre-Hegelian understanding of otherness. To this extent, I am not engaging with the full implications of their work; rather, I am selectively using the diagnostic part of it.

${ }^{9}$ Georg F. W. Hegel, Phenomenology of Spirit (Oxford: Oxford University Press, 1977). All references from Hegel's Phenomenology of Spirit will be provided by indicating the paragraph number in A. V. Miller's 1977 translation.

${ }^{10}$ For a Žižekian reading of Hegel that I am alluding to here see Slavoj Žižek, The Ticklish Subject: The Absent Centre of Political Ontology (London, New York: Verso, 1999). 
when it "destroys the independent object" in a merely 'objective' or natural manner (paras 174-175). Therefore, if the subject is to be able to integrate for herself her opposed views of herself as 'self-consciousness' (as independent, as determining for herself what counts for her) and as 'life' (as being dependent on the given structure of organic desire), she must be able to find some desire that is not simply given but is a desire that comes out of her nature as a self-conscious independent agent per se.

These requirements are met by the subject's having a desire for recognition (Annerkenung) as an independent agent by another self-conscious agent. This is what Hegel means when he writes that self consciousness as desire "achieves its satisfaction only in another self-consciousness" (para 175), and that the goal which lies ahead is "the unity of the different independent self-consciousnesses which ... enjoy perfect freedom and independence: 'I' that is 'We' and 'We' that is 'I'" (paras $175,177)$. The encounter between the two self-conscious agents is the "attempt on the part of each to impose his own subjective point of view on the other and to claim for his own subjective point of view the status of being the "true", the objective, impersonal point of view". ${ }^{11}$ The struggle is therefore not just over the satisfaction of desire but over what is to count as the objective point of view and thus what is to count as the truth. What Hegel succeeds in illuminating here is the inadequacy of approaches that preserve a self-contradictory distinction between the self and its other or the one-sidedness of those approaches which fail to account for a convincing reconciliation between the subjective and the objective point of view. Eventually, what performs the reconciliation for Hegel is the notion of 'Spirit'. Without Spirit, self-consciousness remains abstract and decontextualised.

\footnotetext{
${ }^{11}$ Terry Pinkard, Hegel's Phenomenology: The Sociality of Reason (Cambridge: Cambridge University Press, 1994), p. 59.
} 
However, legitimate objections have been raised at this point concerning the terms of this reconciliation, as it may be said that it takes place in the terrain of selfconsciousness, thus tacitly affirming the priority of the reasoning individual. According to that line of argument, self-consciousness perceives the possible gap between self-certainty, i.e. the subjective take on what is happening, and what is called the 'truth' as a kind of social pathology, a contradiction that must be overcome. The experience of such a gap is what Hegel appeals to as the engine for conceptual and social change, a striving for reconciliation and mutuality in such a context. In other words, it is the self-consciousness's inability to account for its claims on its own terms that drives the striving for unity in the form of a reconciliation between the subjective and the objective point of view. In the master-slave dialectic each has found out that "she cannot identify what is her own without reference to the other's point of view - without, that is, reference to the sociality common to both". ${ }^{12}$ What counts as her own projects for the master cannot be unambiguously identified without incorporating some references to the slave's projects and vice versa.

However, the criticism continues, what unites the two perspectives is the need to establish the priority of a non-contradictory sense of identity for the subject-knower (either the master or the slave). In Hegel's defence, it has been argued that Hegel has been prominent in showing us the incompleteness of this process: what Hegel really implies is that, to the extent pure identity is a mere illusion, the terms of the assimilation performed by self-consciousness remain inherently unstable: the famous Hegelian negation of the negation is nothing other than the very logical matrix of the necessary failure of the subject's teleological activity. ${ }^{13}$ Nonetheless, the counterargument goes, even if we accept that the Absolute Spirit has no positive content of its

\footnotetext{
${ }^{12}$ Ibid, p. 62.

${ }^{13}$ See Slavoj Žižek, The Ticklish Subject, p. 77.
} 
own (a non-metaphysical interpretation of Hegel), and is just the succession of all dialectical transitions, of its impossibility of establishing a final overlapping between the subjective and the objective viewpoint, the logical necessity of the link between the two affirms the hegemonic priority of Reason. ${ }^{14}$

That said, it has also been persuasively argued that Hegel does not aspire to the holism of a 'substance' metaphysics, or to a mystical unification of all in the One. Instead, Hegel's holism is relational in the sense that his self-differentiating holism must include both identity and difference. ${ }^{15}$ However, doubts have been voiced as to whether, in his scheme, Difference and the Other are taken to be ineradicable as the ordering and structuring principles of the whole as opposed to being mere transitory moments, logical categories swept away in the Spirit's actual movement towards a consistent and non-contradictory narrative of the reasoned individual. Precisely for this reason, his philosophical project has been reproached, most prominently by Levinas, for affirming the philosophical imperialism of the privileged self which seeks to lift all contradictions with the external world through a learning process that is nothing other than the 'primordial work of identification'. ${ }^{16}$ Yet, it should be noted that by interpreting the subject's activity of mediation as a movement of appropriation as opposed to Hegel's insistence that it is the repeated failure to achieve this end that is constitutive of 'reality', this latter criticism risks misrepresenting Hegel's corrective

\footnotetext{
${ }^{14}$ See Ernesto Laclau, 'Identity and Hegemony: The Role of Universality in the Constitution of Political Logics’, in Judith Butler, Ernesto Laclau, Slavoj Žižek, Contingency, Hegemony, Universality: Contemporary Dialogues on the Left (London and New York: Verso, 2000), pp. 60-1. Laclau writes: "As in most post-Kantian Idealist systems, Hegel aspires to a presuppositionless philosophy. This means that the irrational - and ultimately contradictory - moment of the thing in itself has to be eliminated. Furthermore, if Reason is going to be its own grounding, the Hegelian list of categories cannot be a catalogue, as in Aristotle or Kant - the categories have to deduce themselves from each other in an orderly fashion. This means that all determinations are going to be logical determinations. Even if something is irrational, it has to be retrieved as such by the system of Reason." ${ }^{15}$ See Robert R.Williams, Recognition: Fichte and Hegel on the Other (New York: State University of New York Press, 1992), pp. 78 and 270.

${ }^{16}$ Levinas Emmanuel, Totality and Infinity, trans. Alphonso Lingis (Pittsburgh: Duquesne University Press, 1969), p. 36.
} 
to Kant. Hegel's unprecedented contribution lies exactly in amending the inadequacies of Kantian formalism through lifting the duality created by the abstractness of an apperceptive self as opposed to an empirical self, ${ }^{17}$ thus providing a form of idealism that avoids solipsism. Hegel, eventually, managed to show that:

...there is no escape from the limitations of external facticity not because there is an abyssal gap between the knowing subject and its object but because we (meaning any self-conscious being) are the limitations of our external facticity: we are what we learn, what we have learned and also what do not and have not learned. ${ }^{18}$

Having said that, Levinas' criticism is not to be lightly dismissed as it does point to an underlying motif in speculative idealism in terms of its understanding of the relationship between tautology and heterology. The heart of the problem lies in what philosophers stipulate as the distinction between relative and absolute otherness. Ultimately, Hegel's treatment of the self/other relation seems to conform to what Kearney alludes to as the relative understanding of otherness ${ }^{19}$. Kearney notes that Plato in the Sophist puts the interrogation of otherness into the mouth of the Eleatic stranger (xenos):

For the Eleatic stranger the other is other only in relation to the same. The other as a distinct class is not comprehensible unless it is considered relative to some other (pros heteron). The complete separation of the same (autos) and other (heteron), of

\footnotetext{
17 See John Mc Dowell, 'The Apperceptive I and the Empirical Self: Towards a Heterodox Reading of "Lordship and Bondage" in Hegel's Phenomenology' in Hegel: New Directions, ed. Katerina Deligiorgi (Montreal: Mc Gill-Queens University Press, 2006).

${ }^{18}$ Kimberly Hutchings, Hegel and Feminist Philosophy (Cambridge: Polity Press, 2003), p. 76.

${ }^{19}$ Richard Kearney, Strangers, Gods and Monsters: Interpreting Otherness (London: Routledge, 2003), p. 16.
} 
being and what is other than being, would be the obliteration (apophasis) of all speech. $^{20}$

For any engagement with the other to be even utterable within the self's horizon of understanding, the other has to undergo a significant transmutation: its absolute otherness as manifested in its unassimilated singularity is irredeemably lost at the expense of its meaningful association with the same. Or more simply put, "any relation with the Absolute makes the absolute relative". ${ }^{21}$ It is on this point that adherents of an absolute interpretation of otherness would castigate Hegel's movement as one that is constituted under the terms of the knowing and appropriating subject and one that inevitably leads to the subsumption of the other's true alterity. Hence, for a thinker like Levinas, the desire to understand is the centre of the problem. For Levinas' concern is to try to understand the other without using the violence of comprehension to do so. To understand the other by comprehension, the argument goes, is to reduce other to self. It is to deprive the other precisely of the very alterity by which the other is other. Even if, as in the case of Hegel, identity is constituted through differentiation and, thus is denied any reification or naturalness, alterity as such is not recognised in its own terms. The task of the next section is to examine these objections in detail.

\section{Levinas and absolute otherness}

\footnotetext{
${ }^{20}$ Kearney, Strangers, Gods and Monsters, p. 15

${ }^{21}$ Ibid
} 
As Bernstein informs us, "Levinas reads the entire project of the history of Western philosophy, whose destiny has been shaped by the classical Greek problematic, as functioning within what he calls "the Same and the Other",.22 For Levinas, the main objective of Western metaphysics has always been to reduce, absorb, or appropriate what is taken to be the other to the primacy of ontology as the discourse uniquely able to discover and describe the ultimate structure of reality. In the process of finding criteria for human action that are universally intelligible and valid for everyone, the philosophical tradition from Parmenides to Heidegger attempted to reduce all forms of otherness to what Levinas, following Plato, calls the same (le même; to auton). ${ }^{23}$ Parmenides stated it in the form: 'thought and being are the same', ${ }^{24}$ with a radicality and simplicity which dissolves difference and otherness in the identification of thought and being. This "imperialistic gesture, a gesture to conquer, master and colonise the Other", reveals the violence committed against the other's singularity or, as Levinas calls it, the other's absolute exteriority (l'autrui) that is not reducible to any reciprocal relationship with the same. ${ }^{25}$ For Levinas, this violence reaches its apotheosis in Hegel:

The ' $\mathrm{I}$ ' is not a being that always remains the same, but is the being whose existing consists in identifying itself, in recovering its identity throughout all that happens to it. It is the primary identity, the primordial work of the identification ... Hegelian phenomenology, where self-consciousness is the distinguishing of what is not distinct,

\footnotetext{
${ }^{22}$ Bernstein, The New Constellation, p. 70

${ }^{23}$ Simon Critchley, The Ethics of Deconstruction: Derrida and Levinas (Edinburgh: Edinburgh University Press, 1999), p. 6.

${ }^{24}$ Cf. Joan Stambaugh, 'Introduction', in Martin Heidegger, Identity and Difference, trans. Joan Stambaugh (New York, Evanston and London: Harper \& Row, 1969), p. 7.

${ }^{25}$ Bernstein, The New Constellation, p. 69.
} 
expresses the universality of the same identifying itself in the alterity of objects thought and despite the opposition of self to self. ${ }^{26}$

Levinas interprets Hegelian phenomenology as affirming "the return of absolute thought to itself, the identity of the identical and the non-identical in consciousness of self recognizing itself as infinite thought, 'without other"'. ${ }^{27}$ Consequently, 'alterity' has no singular metaphysical status outside what is ontologically the same apart from being a 'moment' within the same: "'all exteriority' is reduced to or returns to the immanence of a subjectivity which itself, and in itself, exteriorizes itself". ${ }^{28}$ Levinas boldly seeks to escape this 'philosophical imperialism' of the same by opening the space for an asymmetrical and nonreciprocal relation to the other's alterity and our infinite responsibility to and for the other. The metaphysical other is an "other with an alterity that is not formal, is not the simple reverse of identity, and is not formed out of resistance to the same, but is prior to every initiative, to all imperialism of the same. It is other with an alterity constitutive of the very content of the other."29

For Levinas, we are responsible to alterity as absolute alterity, as difference that cannot be subsumed into the same, into a totalising conceptual system that comprehends and exhausts self and other. To acknowledge the otherness of the other (l'autrui), to keep it from falling back into the other of the same requires Levinas to speak of it as the 'absolute other'. The French word 'autrui' refers to the other human being, "whom I cannot evade, comprehend, or kill and before whom I am called to justice, to justify myself." ${ }^{30}$ It is this radically asymmetrical relation between the I and

\footnotetext{
${ }^{26}$ Levinas, Totality and Infinity, p. 36.

${ }^{27}$ Emmanuel Levinas, Entre nous: On Thinking-of-the-Other, trans. Michael B. Smith and Barbara Harshav (London: The Athlone Press, 1998), p. 137.

${ }^{28}$ Levinas, ibid.

${ }^{29}$ Levinas, Totality and Infinity, pp. 38-9.

${ }^{30}$ Critchley, The Ethics of Deconstruction, p. 5.
} 
the other (a 'relation' that defies reduction to reciprocal equality and, hence, rejects justice as impartiality) that characterises what Levinas calls the ethical relation. The ethical is therefore the location of a point of alterity, or what Levinas also calls 'exteriority', that cannot be reduced to the same. In fact, the ethical 'I' is constituted as a subject "precisely insofar as it kneels before the other, sacrificing its own liberty to the more primordial call for the other". ${ }^{31}$ At the same time, to be regarded ethically, the other must remain a stranger 'who disturbs the being at home with oneself [le chez soi], ${ }^{32}$ who remains infinitely other. The ethical for Levinas is, finally, "a nonviolent relationship to the other as infinitely other". ${ }^{33}$ Unlike the Hegelian narrative of overcoming contradiction and achieving reconciliation, Levinas suggests a journey towards "a pluralism that does not merge into a unity". ${ }^{44}$ To represent the self"s journey towards alterity as a movement which exceeds the circle of the self and goes towards the other without ever turning back, Levinas juxtaposes Abraham's journey to Odysseus', which is the basis for the Hegelian dialectical journey in which alterity simply serves the enhancement of the self: "To the myth of Odysseus returning to Ithaca, we wish to oppose the story of Abraham, leaving his fatherland forever for a land yet unknown."35

By arguing for the incommensurability of the 'Other' with the 'I', Levinas is defending the ethical relation against any reduction to the totality of the same and the other. ${ }^{36}$ Levinas' insistence on the lack of reconciliation and the asymmetrical quality

\footnotetext{
${ }^{31}$ Emmanuel Levinas and Richard Kearney, 'Dialogue with Emmanuel Levinas', in Face to Face with Levinas, ed. Richard A. Cohen (Albany: State University of New York Press, 1986), p. 27.

${ }^{32}$ Levinas, Totality and Infinity, p. 39.

${ }^{33}$ Jacques Derrida, 'Violence and Metaphysics: An Essay on the Thought of Emmanuel Levinas', in Derrida, Writing and Difference, trans. Alan Bass (Chicago: University of Chicago Press, 1978), p. 102.

${ }^{34}$ Emmanuel Levinas, Time and the Other, trans. Richard Cohen (Pittsburgh: Dusquesne University Press, 1987), p. 42.

${ }^{35}$ Emmanuel Levinas, 'The Trace of the Other', trans. Alphonso Lingis, in Deconstruction in Context: Literature and Philosophy, ed. Mark C. Taylor (Chicago: University of Chicago Press, 1986), p. 348.

${ }^{36}$ Bernstein, The New Constellation, p. 70.
} 
of the ethical relation with the other is inaugurating a radical understanding of ethical responsibility where I am always responsible for (to) the other's alterity (l'autrui), regardless of the Other's response to me. It is important to emphasise here that what Levinas understands as 'responsibility' is not a move of ontology's imperial 'I', nor is it a form of co-responsibility "grounded in compassion, benevolence, or empathy"; 37 rather, responsibility is grounded on the non-reciprocity of the ethical relation: "In this sense, I am responsible for the Other without waiting for reciprocity, were I to die for it. Reciprocity is his affair. It is precisely insofar as the relationship between the Other and me is not reciprocal that I am subjection to the Other; and I am 'subject' essentially in this sense". ${ }^{38}$ With subjectivity redefined as subjection to the other's infinite call, Levinas introduces one of the most radical themes of his thought on alterity, the idea that, "as a unique and noninterchangeable 'I', I am substitutable for another". ${ }^{39}$ This idea of substitution, of putting oneself in the place of another is not so much a movement of an appropriating self-consciousness, but what he refers to as a 'passivity', wherein the self is absolved of itself. ${ }^{40}$

However, it is exactly on this point that Derrida questions the intelligibility of Levinas' notion of absolute exteriority. Derrida agrees with Levinas that "the other is the other only if his alterity is absolutely irreducible, that is, infinitely irreducible". ${ }^{41}$ But, contrary to Levinas, who claims that "to make the other an alter ego ... is to neutralize its absolute alterity", Derrida argues that "if the other was not recognized as ego, its entire alterity would collapse”. Against Levinas' reading of Husserl, Derrida

\footnotetext{
${ }^{37}$ Patricia Molloy, 'Face-to-Face with the Dead Man: Ethical Responsibility, State-Sanctioned Killing, and Empathetic Impossibility', in David Campbell and Michael J. Shapiro, Moral Spaces: Rethinking Ethics and World Politics (Minneapolis \& London: University of Minnesota Press, 1999), p. 220. ${ }^{38}$ Emmanuel Levinas, Ethics and Infinity: Conversations with Philippe Nemo, trans. Richard Cohen (Pittsburgh: Duquesne University Press, 1985), p. 98

${ }^{39}$ Emmanuel Levinas, Otherwise than Being: or Beyond Essence, trans. Alphonso Lingis (Dordrecht: Kluwer Academic Publishers, 1981), p. 117.

${ }^{40}$ Ibid, pp. 115-17.

${ }^{41}$ Derrida, 'Violence and Metaphysics', p. 104.
} 
claims that, according to Husserl, "the other as alter ego signifies the other as other, irreducible to my ego, precisely because it is an ego, because it has the form of the ego ... This is why, if you will, he is face, can speak to me, understand me, and eventually command me". ${ }^{42}$ In short, in a dramatic recap of a Hegelian theme, Derrida reminds us that "there is both sameness and radical alterity, symmetry and asymmetry, identity and difference in my relation with the other, and above all in the ethical relation." ${ }^{43}$ For Derrida, without this acknowledgement no ethics would be possible. Pace Levinas, the other is absolutely other only if he is an ego, that is, in a certain way, if he is the same as I: “...without this, no letting-be would be possible and first of all, the letting be of respect and of the ethical commandment addressing itself to freedom. Violence would reign to such a degree that it would no longer even be able to appear and be named." 44

Ultimately, what Derrida's thought invites us to realise is that we can never escape the real practical possibility that we will fail to do justice to the alterity of the other. On a more profound level, this is a mere implication of our inability to escape metaphysics altogether:

[T]here is no sense in doing without the concepts of metaphysics in order to shake metaphysics. We have no language - no syntax and no lexicon - which is foreign to this history; we can pronounce no single destructive proposition which has not already had to slip into the form, the logic, and the implicit postulations of precisely what it seeks to contest. ${ }^{45}$

\footnotetext{
${ }^{42}$ Ibid, p. 157.

${ }^{43}$ Richard Bernstein, The New Constellation, p. 72.

${ }^{44}$ Ibid, p. 172.

${ }^{45}$ Jacques Derrida, Limited Inc. (Evanston: Northwestern University Press, 1988), p. 83.
} 
Derrida has effectively shown that Levinas' language presupposes the very same Heideggerian ontological transcendence it seeks to overcome. While speech can counter the violence of language by disrupting language's pretension to conceptual mastery - like Levinas' notion of the way the ethical is performed in conversation, in a 'saying' that disrupts the 'said' - it must inevitably, to remain intelligible, do some violence and, thereby, affirm aspects of what it resists. ${ }^{46}$ It is for this reason that Derrida argues that an ethical regard requires one to acknowledge this dilemma. The fact that we may recognise that the moment we enter the realm of language and conceptual understanding we commit violence against the other's singularity does not necessarily condemn us to absolute incommensurability. Rather, by admitting the continuing violence of one's own discourse, one commits the least possible violence. On the contrary, the most violent position would precisely be a puritan and selfrighteous commitment to total non-violence. ${ }^{47}$ It is in this sense that Derrida's notion of undecidability should be understood to be the necessary precondition for ethics and politics. Against criticisms that take it to be the very negation of politics and the denial of responsibility, Derrida constantly reminds us that to aspire to a world devoid of the undecidable would be to wish for the demise of politics, "for it would install a new technology, even if it was a technology that began life with the markings of progressivism and radicalism" ${ }^{48}$ It is to this Hegel-inspired Derridian point that we will return at the end of this paper to reach, hopefully, a better understanding of the self/other problematique within the purview of immanence.

\footnotetext{
${ }^{46}$ For a defence of Levinas on this point see Simon Critchley, The Ethics of Deconstruction, pp. 15669.

${ }^{47}$ See Michael J. Shapiro, 'The Ethics of Encounter: Unreading, Unmapping the Imperium', in eds. David Campbell and Michael J. Shapiro. Moral Spaces, pp. 67-8.

${ }^{48}$ David Campbell, 'The Deterritorialization of Responsibility: Levinas, Derrida, and Ethics after the End of Philosophy’, in eds. Campbell and Shapiro, Moral Spaces, p. 51.
} 


\section{Dialogic cosmopolitanism: the assimilative logic of universalism}

Introducing the above discussion into the realm of critical international theory obliges us to examine a critical brand of cosmopolitanism that is significantly inspired by the Hegelian striving for reconciliation between universality and particularity, namely the dialogic cosmopolitanism espoused by Andrew Linklater and Richard Shapcott. ${ }^{49}$ The purpose of this section is to show how their relative understanding of otherness coupled with the thin universalism of their critique usher in an implicit assimilationism in their work. Linklater's seminal work The Transformation of Political Community is an exploration of the possibility of open dialogue with the other and of support for post-sovereign communities in which new articulations of universality and difference can be both imagined and attained. Consciously postMarxist, this approach tends to focus on the emancipatory potential inherent in Habermas' discourse ethics and theory of historical development in order to identify the potential of modern states to transcend the state-centric logic of anarchy as depicted by realists. The key issue for this Habermasian rendition of critical international theory is how to accommodate the Enlightenment's initial defence of universalism with the claim for difference into a single theoretical perspective. In a more profound sense, it is a question of how to strike the right balance between two features of the project of modernity: the ethos of critique and the spirit of cosmopolitanism..$^{50}$

This latter ambition translates into a particularly challenging task which, in many ways, is accountable for Critical Theory's major pitfalls. Specifically, some

\footnotetext{
${ }^{49}$ For an overview of this approach see Andrew Linklater, The Transformation of Political Community (Cambridge: Polity Press, 1998) and Richard Shapcott, Justice, Community and Dialogue.

${ }^{50}$ See Richard Devetak, 'The Project of Modernity and International Relations Theory', Millennium: Journal of International Studies 24, no. 1 (1995), p. 35.
} 
theorists have accused Habermasian Critical Theory of relying on uncritical assumptions about the criteria of judgement. ${ }^{51}$ This point can best be understood in terms of what Kimberly Hutchings describes as the paradoxical oscillation of the Kantian critical project "between limitation and legislation". 52 This is a wider philosophical puzzle that is constantly being reproduced since Kant's unsuccessful attempt to bridge the gap between Nature and Freedom in his Critique of Judgement. In his Critique of Pure Reason Kant set out to define the limitations of critique's legitimate function as the conditions of its possibility. Simultaneously, Kant accepted the fact that if theoretical reason is to escape the "dangers of unfounded dogmatism on the one hand and rampant scepticism on the other", it has to legislate for itself the boundaries of its legitimate application. ${ }^{53}$ As a result the Kantian critique's resolution to the problem of arbitrariness and relativism is based on an exclusionary practice where "pure reason is both on trial and judging" 54 legislating for itself the appropriate preconditions of communication and defining the legitimate boundaries of conversation.

In many ways, Linklater's leaning on the Habermasian rendition of discourse ethics is rehearsing the ambiguities of the Kantian critical project. Discourse ethics' legitimacy rests on a thin proceduralism which allows it to appear as an allencompassing framework for accommodating diverse ethical claims. At the same time, pluralism is not essentially accepted at face value but only as a rhetorical device since agreement is understood as convergence around a set of supposedly non-

\footnotetext{
${ }^{51}$ See Kimberly Hutchings, 'The Nature of Critique in Critical International Relations Theory' and Nick J. Rengger, 'Negative Dialectic? The Two Modes of Critical Theory in World Politics', both in Critical Theory and World Politics, ed. Richard Wyn Jones (London: Lynne Rienner, 2001).

${ }^{52}$ See Kimberly Hutchings, Kant, Critique and Politics (London and New York: Routledge, 1996), p. 12. The same critique is successfully pursued in Schapcott, Justice, Community and Dialogue, p. 97.

${ }^{53}$ Hutchings, Kant, Critique and Politics, p. 37: "The critic legislates, governs and judges on behalf of reason, but always also bears witness to the impossibilities of that legislation, government and judgment, except on the basis of hypothetical as-if identifications or hopes."

${ }^{54}$ Ibid, p. 12.
} 
metaphysical presuppositions which are accepted on the basis of their alleged neutrality. What is usually silenced is that these decontextualised 'impartial rules' of engagement with difference are reflecting a particular, historically conditioned response to the challenge of diversity, "that of an 'overlapping consensus' of diverse worldviews around a minimal, non-metaphysical morality". ${ }^{55}$ This is a distinctively European understanding of accommodating difference arising out of the devastating experience of religious strife and intransigence during the religious wars of $16^{\text {th }}$ and $17^{\text {th }}$ century Europe. Ever since, tolerance was equated with the effort of establishing the impartial means by which different conceptions of the good can coexist and sort out their differences in peace. Impartiality and stability were elevated to the status of the only acceptable public values while comprehensive conceptions of the good life were reduced to mere aesthetic preferences or tastes on which there can be no rational agreement.

Linklater insists that the ethical universalism of Critical Theory does not display any inherent aversion to cultural diversity and difference nor does it tacitly imply a secret agenda of "bringing aliens or outsiders within one homogeneous, moral association". ${ }^{56}$ Discourse ethics, the argument goes, remains faithful to procedural universalism and the possibility of an 'undistorted communication' that would lead to a cross-communal understanding through the force of the better argument. What remains unsaid, according to Shapcott, is that conversation oriented towards universalism is only achievable between subjects who have reached a 'postconventional' level of consciousness -that is, morally mature, reasonable beings

\footnotetext{
${ }^{55}$ Timothy S. Shah, 'Making the Christian World Safe for Liberalism: From Grotius to Rawls', in eds. David Marquand and Roland L. Nettler, Religion and Democracy, (Oxford: Blackwell Publishers, 2000), p. 122

${ }^{56}$ See Linklater, The Transformation of Political Community, pp. 87-100. See also Andrew Linklater, 'The Achievements of Critical Theory', in International Theory: Positivism and Beyond, ed. Steve Smith, Ken Booth and Marysia Zalewski (Cambridge: Cambridge University Press, 1996), p. 291.
} 
able to be governed by the unforced force of the better argument- and as such it is "an advocacy of a particular conception of agency". ${ }^{57}$ Shapcott goes on to imply that this particular type of agency privileges a culturally specific type of community which has traditionally been developed in the West by citing Seyla Benhabib's reference to "a secular, universalist reflexive culture in which debate, articulation and contention about value questions as well as conceptions of justice and the good have become a way of life". ${ }^{58}$ Shapcott's critique has successfully shown that discourse ethics raise obstacles to communication with the radically different through exactly the same means employed to achieve universal inclusion. ${ }^{59}$

Commenting on the Habermasian communicative ethics, Brown equally questions the potentiality of the Habermasian Critical Theory to embrace difference and points to the fact that the Habermasian notion of 'ideal speech situation' ${ }^{60}$ relies uncritically on a Western view of rationality as a transcultural and transhistorical criterion of judgement: "To believe in the desirability of transparency [the idea that, in principle, human communication could be free from distortion] comes close to a commitment to the elimination of difference, to a denial that the Other could be accepted as the Other." ${ }^{\circ 1}$ Pluralism in this sense is understood as a platform of coexistence under the unifying effect of Western rationality and not as a true

\footnotetext{
${ }^{57}$ Shapcott, Justice, Community and Dialogue, p. 120.

${ }^{58}$ Seyla Benhabib Situating the Self: Gender, Community and Postmodernism in Contemporary Ethics (Oxford: Polity Press, 1992), p. 42 cited from Shapcott, Justice, Community and Dialogue, p. 121 (note $51)$.

${ }^{59}$ For a recent reformulation of Linklater's argument where he seems to incorporate both Hutchings' and Shapcott's critique and cautions against the exclusionary and assimilationist potentials in discourse ethics see Andrew Linklater, 'Dialogic Politics and the Civilising Process', Review of International Studies 31 (2005): 141-54. Yet, he still advocates a thin version of the discourse approach as 'the best means of advancing the civilising process in international relations' (my emphasis).

${ }^{60}$ For an argument though that Habermas has abandoned the misleading concept of 'ideal speech situation' see Jürgen Haacke, 'Theory and Praxis in International Relations: Habermas, Self-Reflection, Rational Argumentation', Millennium: Journal of International Studies 25, no. 2 (1996), p. 265.

${ }^{61}$ Chris Brown, "“Turtles All the Way Down": Anti-Foundationalism, Critical Theory and International Relations', Millennium: Journal of International Studies 23, no 2 (1994), p. 221.
} 
affirmation of otherness. In this respect, discourse ethics "prescribes not only the procedure but also the content of dialogue, that is, of what are acceptable statements and topics, according to an already given definition of the moral realm, one which is constituted prior to the engagement with the other". ${ }^{62}$ It comes, then, as no surprise that Walker considers Linklater's project as the latest edition of idealism “except that this latest representative of the idealists has begun to temper his universalistic tendencies with an appropriately late-modern attention to difference and diversity", ${ }^{63}$

Instructed by Linklater's shortcomings, Shapcott's thin cosmopolitanism aspires to introduce a via media between the unreflected universalism of liberal cosmopolitanism, the slightly subtler universalism of Frankfurt School Critical Theory and the radical anti-universalism of post-structuralism. To achieve this objective, Shapcott employs Gadamerian hermeneutics in an attempt to provide a nonfoundational account of truth that would allow genuine communication between self and other. Philosophical hermeneutics, according to Shapcott, takes it that "the capacity for cross-cultural understandings is real and accompanies the development of language itself". ${ }^{64}$ In the philosophical hermeneutic account, "the other is understood as a linguistically constituted agent from the start and, therefore, inherently capable of understanding and conversation". 65 The crux of this approach is the denial of any determinate understanding of the other prior to actual engagement. Conversation rests on the notion that "understanding refers to the subject matter (Die Sache) of conversation, to what is said, not the sayer, the text, not the writer". ${ }^{6}$

\footnotetext{
${ }^{62}$ Shapcott, Justice, Community and Dialogue, p. 113.

${ }^{63}$ Robert B. J. Walker, 'The Hierarchicalization of Political Communities', Review of International Studies 25 (1999), p. 155. See also Beate Jahn, 'One Step Forward, Two Steps Back : Critical Theory as the Latest Edition of Liberal Idealism', Millennium: Journal of International Studies, 27, no. 3, (1998), pp. 613-641.

${ }^{64}$ Shapcott, Justice, Community and Dialogue, p. 235.

${ }^{65}$ Ibid, p. 167.

${ }^{66}$ Ibid, p. 140.
} 
Although Shapcott's approach aspires to avoid assimilationism by pointing to our historical situatedness "that always informs our understandings", ${ }^{67}$ Shapcott himself does not deny that philosophical hermeneutics and discourse ethics hold in common the argument that "dialogue requires that agents are prepared to question their own truth claims, respect the claims of others and anticipate that all points of departure will be modified in the course of dialogue". ${ }^{68}$ Shapcott is right to point out that philosophical hermeneutics do not share the same interest in achieving a 'thick' kind of agreement but it is rather oriented towards the much thinner goal of understanding. One, however, wonders whether even this latter goal does not previously require the affirmation of the postconventional agent. Even if philosophical hermeneutics denounces the lapsus of determining universal principles for the conversation prior to the dialogical engagement, the moment of assimilation occurs in the argument that "[r]easoned conversation is a property of all humans who possess language". 69

Shapcott is, of course, making the subtle point that the Gadamerian acount of conversation does not share the Habermasian conviction that "the capacity for thinking universally and post-traditionally... is a product of all who possesses (sic) language ${ }^{, 70}$. In that sense, he claims, the qualities that characterise genuine dialogue cannot be confined to the 'enlightend' or 'post-conventional' individual. Shapcott insists that participants in a Gadamerian conversation are oriented towards the much more inclusive purpose of understanding rather than seeking rational agreement on 'thick' moral principles that invite exclusion or assimilation. By following Benhabib

\footnotetext{
${ }^{67}$ Ibid, p. 144.

${ }^{68}$ Andrew Linklater cf. Shapcott, ibid., p. 169.

${ }^{69}$ Shapcott, ibid, p. 166. Shapcott acknowledges this criticism but he argues that while philosophical hermeneutics cannot escape the assimilationist moment altogether, it reduces that moment significantly (ibid, p. 165, note 101).

${ }^{70}$ Richard Shapcott, 'Cosmopolitan Conversations: Justice, Dialogue and the Cosmopolitan Project', Global Society, Vol. 16, no. 3 (2002), p. 239.
} 
in dropping the Habermasian principle of Universalisation (U), Shapcott is confident that philosophical hermeneutics may forge new forms of non-assimilatory solidarity and community.

Despite its inclusive potential, however, Shapcott's dialogic cosmopolitanism remains ambiguously torn between an understanding of language as a nonexclusionary ontological ground for conversation and the promotion of the cosmopolitan project. In fact, one is left wondering here whether the operation was successful but the patient has, unfortunately, passed away. With the absence of a normative consensus on the principles of conversation, Shapcott's account may diminish the chances of assimilation but at the expense of his cosmopolitan intentions. Even if we accept that his model is less exclusionary than Habermas', there is no sufficient ground to accept that linguistically constituted agents will engage in revitalising cosmopolitan solidarities instead of resorting to violence and dissent. In other words, in trying to avoid the assimilatory moment altogether Shapcott allows a gap between his ontology (language) and the emancipatory content of his prescription (thin cosmopolitanism) that is never persuasively addressed. Since, then, his cosmopolitan aspirations do not necessarily follow from his ontological givens, his commitment to a non assimilatory model of conversation serves only to dissimulate the violence of his discourse. In contrast, by accepting the necessary trade-off between assimilation and cosmopolitanism through the act of presupposing agents committed to principles of rational agreement, Habermas seems to be offering a defence of the cosmopolitan project less fraught with -but, of course, not devoid ofthe pretensions of non-violence than Shapcott's non assimilative version of cosmopolitanism. 


\section{Voices of dissidence in IR: oscillating between assimilation and incommensurability}

Post-structuralist theories of international relations are programmatically driven by an unconditional attentiveness to difference as well as a suspicion towards practices of unjustified exclusion. Ever since post-structuralist approaches were introduced in the discipline by Ashley's challenge to Waltz's mainstream neorealist project, ${ }^{71}$ the critique of what was seen as the reification of historically conditioned power structures, such as anarchy and sovereignty, was associated with an almost strategic preoccupation with expanding the realm of resistance. As George and Campbell proclaimed in a special edition containing landmark articles for post-structuralist approaches in the field:

The (poststructuralist) project is a search for thinking space within the modern categories of unity, identity, and homogeneity; the search for a broader and more complex understanding of modern society which accounts for that which is left out - the other, the marginalized, the excluded. ${ }^{72}$

Similarly, in their path-breaking article 'Reading Dissidence/Writing the Discipline', Ashley and Walker explicitly raised the question of how do we account for the claims of those that have been marginalised by mainstream interpretations of

\footnotetext{
${ }^{71}$ See Richard K. Ashley, 'The Poverty of Neorealism', in Neorealism and its Critics, ed. Robert O. Keohane (New York: Columbia University Press, 1986), and Richard K. Ashley, 'Untying the Sovereign State: A Double Reading of the Anarchy Problematique', Millennium: Journal of International Studies 17, no. 2 (1988).

72 Jim George and David Campbell, 'Patterns of Dissent and the Celebration of Difference: Critical Social Theory and International Relations', International Studies Quarterly 34, no. 3 (1990), p. 280.
} 
international relations with their emphasis on territoriality. ${ }^{73}$ Ashley and Walker's response to this challenge is to announce a critical theorising that calls for the questioning of all boundaries and established hierarchicalisations of power. The central issue, however, here is how can one engage in real conversation with the other and at the same time escape the 'violence' of freedom? This uneasiness in postsructuralist international thought has been typified by William Connolly as the 'second problem of evil' ${ }^{74}$ :

The second problem of evil is the evil that flows from the attempt to establish security of identity for any individual or group by defining the other that exposes sore spots in one's identity as evil or irrational...Is it possible to counter the second problem of evil without eliminating the functions served by identity? ${ }^{75}$

Ashley and Walker are aware of the paradoxical status of their critique but they insist that the purpose of theorising from a 'register of freedom' can still be sustained if we construe this move as a project of 'infinite subversion' of sovereign authorities or as "theorising from the borderlines and as theorising from the void or no place". 76

Some critics have been particularly dissatisfied by international poststructuralist thought's difficulty to justify the legitimacy of its own critical discourse. Attacked for rehearsing the inadequacies of the Kantian critical project, post-

\footnotetext{
${ }^{73}$ See Richard K. Ashley and Robert B. J. Walker, 'Reading Dissidence/Writing the Discipline: Crisis and the Question of Sovereignty in International Studies', International Studies Quarterly 34, no. 3 (1990), pp. 367-416.

${ }^{74}$ In Connolly's Augustine-inspired analysis, the second problem of evil is a temptation developing out of the necessity imposed by the first problem of evil. The latter refers to the 'fundamental unfairness of life' and answers to the question: who is responsible for the existence of evil in the world given God's goodness and omnipotence? See Connolly, Identity/Difference: Democratic negotiations of political paradox, pp. 1-15.

${ }_{75}$ Connolly, Identity/Difference: Democratic negotiations of political paradox, p. 8.

${ }^{76}$ Hutchings, Kant, Critique and Politics, p. 162.
} 
structuralism's inability to secure the status of its own critique is attributed to its strategic preoccupation with alterity. ${ }^{77}$ In other words, quite ironically, what was perceived to be post-structuralism's critical credentials is eventually taken to pose the main impediment for its engagement with alterity in its own terms. In this regard, Shapcott is right to point out that "[i]n this conversation one engages with the other, not in order to understand them per se, but rather in order to prevent a further hardening of boundaries that limits their's [sic] and one's own freedom... whereby communication with the other is over-determined by the strategic purpose of expanding the realm of freedom". ${ }^{78}$ Again, critique's attempt to legitimise its own goals, in this case opening new spaces for the inclusion of the excluded and marginalised, is premised on a blanket acceptance of a certain mode of subjectivity. The agent of critique is a priori taken to be a self-reflective individual willing to decentre herself and to question her own beliefs. The spectre of the post-conventional agent, a product of a specific civilisation with a particular view of freedom understood as emancipation, is again haunting the terms of the communication with the other.

Based on a relative understanding of otherness, Ashley and Walker's account of freedom may avoid the pitfalls of an over-reliance on the Habermasian objective of emancipation but their implicit assumption is that the other would be willing to allow such a substantive transformation of herself that the final encounter would resemble more of a process of assimilation than unconditional conversation. ${ }^{79}$

\footnotetext{
${ }^{77}$ See Shapcott, Justice, Community and Dialogue and Hutchings, Kant, Critique and Politics.

${ }^{78}$ Shapcott, Justice, Community and Dialogue, p. 103.

${ }^{79}$ It is fairly indicative of the assimilative moment in the poststructuralist thought that support for diversity is neatly "clothed in unambiguously universalistic garment". Linklater characteristically remarks that this late humanistic ethics of freedom "may be the final repository for the damaged hopes of the Enlightenment and the sole surviving refuge for a modernity which has shed its utopian delusions" (Linklater, The Transformation of Political Community, p. 72).
} 
Despite its emphasis on freedom and emancipation, this strand of international post-structuralist thought continues to rely heavily on a Kantian interpretation of ethics as an expression of an autonomous agent that interacts with alterity after its constitution as a moral subject. Hence, encountering the other can only be perceived in relative terms, meaning the self recognises the other only insofar as it relates to her on the basis of fixed identifications prior to the actual engagement. In contrast to the instrumentality of an approach strategically oriented to freedom, David Campbell offers an alternative post-structuralist ethics inspired by Levinas' work. Campbell attempts to circumvent the traditional ethical approaches in IR which are mainly based on either deontological or utilitarian premises for justifying moral conduct. These approaches perceive the subject of politics and ethics as a unified moral agent ontologically prior to its engagement with the other. In contrast, Campbell, following Levinasian insights, seeks to reconstruct the possibility of an ethics as infinite responsibility towards the other. In pursuit of this end, however, Campbell castigates Levinas for compromising his infinite commitment to the other when confronted with the problem of the Third (le tiers) in politics. Specifically, Campbell identifies an insidious danger of 'political totalitarianism' in Levinas' potential limiting of responsibility in view of the third Other and seeks to respond to this challenge via Derrida's notion of undecidability. ${ }^{80}$ Derrida's account of undecidability, of the

\footnotetext{
${ }^{80}$ Campbell, The Deterritorialization of Responsibility', p. 42. I am well aware that critics like Neumann, Campbell and Shapiro, taking their lead from Levinas' reluctance to condemn the Israeli massacres commited against the Palestinians in the Sabra and Chatila refugee camps, accuse Levinas of partisanship wholly incompatible with his non-anticipatory ethics of encounter. However, I am inclined to think that those critics have misread Levinas on this point. As Jacob Schiff has shown very persuasively, critics who tend to see an inconsistency in Levinas here share a 'redemptive vision of the political' that Levinas is trying to do away with. Ultimately, Levinas ethics of proximity, thus interpreted, tend to come closer to, yet not wholly identifiable with, the Derridian ambivalence of the lesser violence. See Campbell, 'The Deterritorialization of Responsibility', pp. 38-39; Iver Neumann, The Uses of the Other: 'The East' in European Identity Formation (Minneapolis: University of Minnesota Press, 1999), pp 16-18; Shapiro, 'The Ethics of Encounter: Unreading, Unmapping the Imperium', pp. 68-71; Jacob Schiff, 'The Trouble With 'Never Again!': Rereading Levinas for
} 
madness of the decision, acknowledges this dilemma and suggests the need for a 'double contradictory imperative' wherein one acknowledges that in making a decision one is simultaneously asked to calculate the incalculable, to experience the possibility of an impossible justice manifested in doing justice and injustice to others by giving priority to some or one and not others or another. ${ }^{81}$ The need to respond to 'two contradictory injunctions' demonstrates that questions of responsibility are not clear-cut and cannot be decided in a programmatic way prior to the engagement with the other. ${ }^{82}$

Nonetheless, Campbell's reservations for an uncritical endorsement of Levinasian ethics may be justified for more reasons than he deems necessary. Firstly, in its effort to escape the assimilative effects of traditional moral theory, the ethics of radical interdependence run the risk of throwing the baby out along with the bath water. As we have already discussed, Levinas develops an absolute view of ethical conduct that is located in the ineradicable difference between 'I' and the 'Other'. The ethical relationship is one in which I respond to the other qua her or his alterity on the basis of a 'response-ability' ${ }^{83}$ In so far as the other cannot be known, cannot be negotiated with since any such move would irreparably compromise his or her alterity, I can only respond passively. Levinas insists that this has the meaning of rejecting the traditional discourse of equality as responsible for assimilating the other's singularity. Nonetheless, some critics detect in this move a complete disregard

Genocide Prevention and Critical International Theory', Millennium: Journal of International Studies, 36, no.1 (2007), pp. 27-47.

${ }^{81}$ Campbell, 'The Deterritorialization of Responsibility', pp. 44-50.

${ }^{82}$ To this extent, Campbell's argument shares affinities with Connolly's agonistic democratic ethos in which engagement with otherness involves contesting and renegotiating fixed standards of exclusion and judgement. See William E. Connolly, The Ethos of Pluralization (Minneapolis: University of Minnesota Press, 1995).

${ }^{83}$ George Trey, Solidarity and Difference: The Politics of Enlightenment in the Aftermath of Modernity (Albany: State University of New York Press, 1998), p. 132. 
"for the needs of the self and for the other's responsibility to the self" ${ }^{84}$ which ultimately proves unsustainable and self-defeating. If the Levinasian objection to the Habermasian communicative ethics is the elimination of radical difference, it is the self's paralysing subordination to the absolute ineffability of otherness that is authoritative in Levinas' ethics of proximity. ${ }^{85}$

Surprisingly, however, Campbell's recourse to Derrida as a corrective to Levinas' absolute understanding of otherness, though inspired by deconstruction's critical ambivalence, eventually fails to deliver its promise. Let me explain myself: if genuine responsibility is generated within the ethical space of the Derridian undecidable, then the call for "a different configuration of politics, one in which its purpose is the struggle for - or on behalf of - alterity, and not a struggle to efface, erase, or eradicate alterity", ${ }^{86}$ does not remain faithful to the experience of aporia in every decision and ends up being a reversed form of totalising universalism.

Campbell is right to evoke Derrida and argue for a politics which enacts the double injunction. But, in so far as he is reconfiguring politics as a struggle for alterity, he seems to deviate from this ethical commitment. ${ }^{87}$ Rather, it is one of Derrida's lessons

\footnotetext{
${ }^{84}$ See critique by Shapcott, Justice, Community and Dialogue, p. 105.

${ }^{85}$ See Trey, Solidarity and Difference, p. 142.

${ }^{86}$ Campbell, 'The Deterritorialization of Responsibility', p. 50. In a recent forum in International Relations on the role of IR scholars as intellectuals in international politics, Campbell restates this 'ethico-political imperative' for a politics on behalf of alterity (see David Campbell, 'Beyond Choice: The Onto-Politics of Critique', International Relations 19, no. 1 (2005), pp. 132-3). While his understanding of critique as an everyday intervention in the world is an undisputed part of the critical enterprise, his enactment of the critical ethos rests on a blanket affirmation of alterity which, ironically, betrays critique's commitment to an unremitting labour of self-examination and reflection identified by Hegel as 'the labor of the negative' (Arbeit des Negativen) (Georg F. W. Hegel, Phenomenology of Spirit, para. 19).

${ }^{87}$ See the exchange between Warner and Campbell (Daniel Warner, 'Levinas, Buber and the Concept of Otherness in International Relations: A Reply to David Campbell', Millennium: Journal of International Studies 25, no. 1 (1996), pp. 111-28 and David Campbell, 'The Politics of Radical Interdependence: A Rejoinder to Daniel Warner', Millennium: Journal of International Studies 25, no 1 (1996), pp. 129-41). Campbell derides Warner's plea for an energising ethics of responsibility on the grounds that this seems to be 'an act of recidivism that takes us back to a perspective of deracinated ethics and denuded politics' (p. 138). But, if politics is constructed as 'the struggle for, or on behalf of alterity', then Campbell is guilty of the same sin. This 'figuration of politics' is equally informed by a strategic concern that threatens to degenerate radical interdependence into a defence of a reversed totality.
} 
that violence in the form of arbitrary authority is an inevitable part of the madness of the decision. Undecidability implies that a truly critical attitude towards alterity involves an always precarious commitment to the 'lesser violence'. ${ }^{88}$

In other words, by adding an abstract prescription to his critique, Campbell seems to re-enact the paradox of the politics of critique: whenever critique pretends to secure an authoritative ground it undermines its legitimacy. With all sympathy for the 'excluded', the 'victimised' and the 'disempowered', our critical reflexes against the totalising aspects of traditional morality should not be exhausted in a defence of a reversed totality, this time in the form of radical alterity. ${ }^{89}$ Exclusion is always an exercise of power, as Carl Schmitt has persuasively shown us, but so is the exclusion of the exclusion. In thinking that they have found a point of opposition to domination by way of choosing 'deterritorialization' over 'territoriality', post-structuralists tend to become co-opted by the same logic they seek to transgress: it is by overlooking that the very point of opposition is the instrument through which domination works that the powers of domination are reinforced. Judith Butler explains this most lucidly: “Dominance appears most effectively precisely as its 'Other'. The collapse of the dialectic gives us a new perspective because it shows us that the very schema by which dominance and opposition are distinguished dissimulates the instrumental use that the former makes of the latter." 90

\footnotetext{
${ }^{88}$ Derrida, Writing and Difference, p. 313, note 21.

${ }^{89}$ See also Bernstein, The New Constellation, p. 310: 'despite all professed scepticism about binary oppositions, there has been a tendency in many "postmodern" discourses to reify a new set of fixed oppositions: otherness is pitted against sameness, contingency against necessity, singularity and particularity against universality, fragmentation against wholeness. In each case it is the former term that is celebrated and valorized while the latter term of these oppositions is damned, marginalized, exiled.'

${ }^{90}$ Judith Butler, 'Restaging the Universal: Hegemony and the Limits of Formalism', in Butler, Laclau and Žižek, Contingency, Hegemony, Universality, p. 28.
} 


\section{Concluding Remarks}

This paper was principally concerned with the way some sophisticated critical approaches in IR tend to reproduce the paradoxes of the politics of critique in their engagement with the self/other problematique. It has been suggested that their understanding of otherness is theoretically informed by the two antithetical philosophical responses to the enigma of alterity, namely relative vs. absolute otherness. Hegel's attempt to show the inadequateness and self-subversiveness of abstracted forms of universality have alerted us to the illusions of pure identity but have also forced us to confront the limits of a relative engagement with otherness. In contrast, Levinas' alternative understanding of alterity calls for a relationship between self and other that regards heteronomous responsibility towards the other as prior to any consciousness or intentionality required for the self's awareness of and capacity for communication but achieves that at the expense of rendering the other almost unintelligible. Derrida, perhaps too hastily, agrees with Levinas in identifying a totalising impetus in Hegel's logic; yet, when it comes to the issue of how we relate to the other Derrida recognises a certain indispensability in Hegel. Ultimately, Derrida's critique of Levinas reminds us that there can be no relation to alterity outside the horizon of immanence and invites us to accept the inevitability of committing violence to alterity as a condition of the possibility of even speaking intelligibly about it.

Moving to critical international theory, despite dialogic cosmopolitanism's, emphasis on solidarity and reconciliation between universality and difference, its critical discourse remains beset by the contradictions of the Kantian critical project: 
formalism's arbitrariness and the inability of reason to justify the grounds for its legislative authority. In fact, both dialogic cosmopolitan responses to pluralism and Foucauldian post-structuralist IR theory hold that the purpose of freedom is best achieved through the exercise of critique. As such they find themselves entangled in the paradoxes of the politics of critique just like Kant. This has direct ramifications on the possibilities for communication between radically different cultures, since interpreting universality as resting on procedural impartiality (discourse ethics in Linklater) or a prediscursive ontology (language as the human condition in Shapcott) or, even, construing freedom as the capacity of all human beings to exercise critique (Ashley and Walker) is already a judgement prior to the actual engagement with the other that threatens to reduce their version of universality to a defence of another exclusionary particularism.

Among post-structuralist approaches, Campbell's ethics of radical interdependence deserves a special attention since it calls for a relationship with alterity in its own terms and, thus, less predetermined by the strategic demands of the interaction. However, Campbell's ethical responsibility to the other allows limited space for the other's responsibility to the self. In parallel, it seems that the Levinasian concern for the inviolability of the other renders alterity almost inaccessible. In the final analysis, post-structuralist critique, when fixated with the purposive valorisation of heteronomy as opposed to autonomy, is always in danger of substituting one totality for another, thus becoming co-opted by the dominant Western discourse of universalism as the legitimate, politically correct and, eventually, domesticated voice of dissidence. This propensity of universality to be contaminated by the particular contexts it seeks to transcend seems to be a direct offshoot of the Derridian contention that there can be no unthematisable and non-violent ethical relation to the other 
outside the ontological thematisation performed irreducibly by language. Claims that fail to remain thoroughly conscious of this caveat by slipping into a certain kind of normative prescription risk compromising their critical credentials. By understanding critical normativity as total non-violence towards, or unreflective affirmation of, alterity they tend to relapse to precritical paths, i.e. either a particularistic, assimilative universalism with pretensions of true universality or radical separatism and the impossibility of communication with the other.

This latter aphorism may easily leave us with the disconcerting impression that critical theorising in IR will always be bedeviled by the failure of grounding the authority of critique. It is not the purpose of this paper to prescribe passivity exactly because it does not understand critique as a practice that can either succeed or fail. ${ }^{91}$ For this reason, it does not perceive the impossibility of theoretically overriding the self/other divide without reproducing the terms of its re-emergence as a source of discouragement; rather, it is a failure we should -in a manner similar to Heidegger's but, perhaps, less fatalistically- heroically assume provided we develop a proper understanding of the terms of this failure. This paper has not argued that the critical IR approaches examined here are not conscious of the persistency of the self/other enigma. Rather, it has attempted to show that, to the extent critical thinking in IR theory either fails to adequately address its ungroundable universalism or instantiates a puritan ideal of eliminating injustice against alterity, it winds up betraying the key element of a critical attitude towards difference. Namely, the idea that the irresolvability of the self/other conundrum is at the same time the condition of possibility for pursuing it. What is, perhaps, more important than seeking a final overcoming or dismissal of the self/other opposition is to gain the insight that it is the

\footnotetext{
${ }^{91}$ For an elaboration of this point see Hutchings, Kant, Critique and Politics, pp. 189-91.
} 
perpetual striving to preserve the tension and ambivalence between self and other that rescues both critique's authority and function.

Word count: 11, 025 